\title{
Some Unknown Arcid Bivalves from the Turonian (Late Cretaceous) of Central India
}

\author{
S. Kumar ${ }^{1}$ Jai P. Gautam² ${ }^{2}$ B. Pandey ${ }^{3}$, D. B. Pathak ${ }^{4}$, Anand K. Jaitly ${ }^{5}$ \\ Stratigraphy and Invertebrate Palaeontology Laboratory, Centre of Advanced Studies in Geology \\ Banaras Hindu University, Varanasi 221 005, India
}

\begin{abstract}
Five arcid bivalves have been recorded for the first time from the Turonian (Late Cretaceous) sediments exposed in the form of the Nodular Limestone Formation of the Bagh Group, Lower Narmada Basin of central India. These benthic bivalves are represented by Barbatia (Cucullaearca) cf. clellandi Stoliczka, Breviarca baghensis sp. nov., Glycymeris sp., Trigonarca camerunensis Riedel, Trigonarca galdrina d'Orbigny and Grammatodon cf. japeticum Forbes. All these five species have been systematically described with remarks on their occurrences outside the Narmada Basin.
\end{abstract}

Keywords: Bivalvia, Arcid, Taxonomy, Late Cretaceous, Central India.

\section{Introduction}

The superfamily Arcoidea, though having its origin in Paleozoic have much evolutionary diversification during Mesozoic which continued further to Recent. Most of them are known from shallow marine settings with a benthic mode of life. In the Indian subcontinent these are fairly represented in the Jurassic (Jaitly et al., 1995). During Cretaceous Period, there is a global dispersal of these arcids from equatorial to polar regions with some modification in taxodont dentition (Buick, 2009). The modification in dentition is also accompanied by change to duplivinicular ligament with thickening of anterior and posterior ends due to addition of material (Thomas et al., 2000). With the increase in the global temperature during Late Cretaceous there is sudden decline in the density of these arcids (Souji and Radhakrishnan, 2013) as we also observed in the Bagh Group. The arcids of the Bagh Group, Lower Narmada Basin of central India have both semi-infuanal and epifaunal mode of life. The semi-infaunals preferred sandy to muddy substrate of the shallow marine environment while the epifaunal are nestlers with byssus sinus in the middle of the ventral margin and are found in hard calcareous substrate. The morphology and small size of these nestlers promote relatively quiet and nutrient deficient habitat.

The present contribution includes the systematic description of the bivalve species based on 8 moderately well preserved specimens collected from Turonian sediments cropping out in the form the Nodular Limestone Formation of the Bagh Group exposed near the villages Chakrur, Sitapuri and Rampura of Dhar district, Madhya Pradesh. Out of the 5 species differentiated, Trigonarca camerunensis Riedel recorded for first time from the Indian subcontinent, Barbatia (Cucullaearca) cf. clellandi Stoliczka, Trigonarca galdrina d'Orbigny and Grammatodon cf. japeticum Forbes are new to the Narmada basin while Breviarca baghensis is new to the science. Almost all the specimens are disarticulated and also subjected to some digenetic alteration. The record of these five species from the Narmada Basin may in turn help in better understanding of the palaeobiogeography in and around the Indian subcontinent during Turonian interval (Late Cretaceous).

\section{Geology of the Area}

Narmada Basin formed by rifting in the middle part of the Indian sub-continent through twisting and northward movement of the Indian plate resulted in the formation of an intracratonic graben delimited by Narmada-Son Lineament (Biswas, 1982, 1999, 2005-6; Gupta et al., 1972, 1997; Chandra, 1977; Acharya et al., 1998; Tripathi, 2006; Khan, 2015; West, 1962; Merh, 1995; Anand and Rajaram, 2004). The Cretaceous sediments directly overlie the crystalline rocks of Precambrian age. These Cretaceous sediments of the Narmada Basin are popularly known as ,Bagh Beds se (Fig. 1) and now recognized as Bagh Group (Jaitly and Ajane, 2013). The geology and stratigraphy of the ,Bagh Beds ${ }^{\text {ee }}$ have been variously reviewed and modified from time to time by several workers ( Bose, 1884; Rode and Chiplonkar, 1935; Singh and Srivastava, 1981; Akhtar and Khan, 1997; Kumar et al., 1999). However, it has been comprehensively reviewed in recent years by Tripathi (2006) and Jaitly and Ajane (2013), which is followed here in the present work. The Bagh Group of the Narmada basin has been differentiated into Nimar Sandstone, Nodular Limestone and Coralline Limestone formations in ascending order. Further, the Nimar Sandstone Formation is subdivided into Bagh Cave and Baria members while the Nodular Limestone Formation into Karondia and Chirakhan members in ascending order (Table 1). 


\section{International Journal of Science and Research (IJSR) \\ ISSN (Online): 2319-7064}

Index Copernicus Value (2013): 6.14 | Impact Factor (2014): 5.611

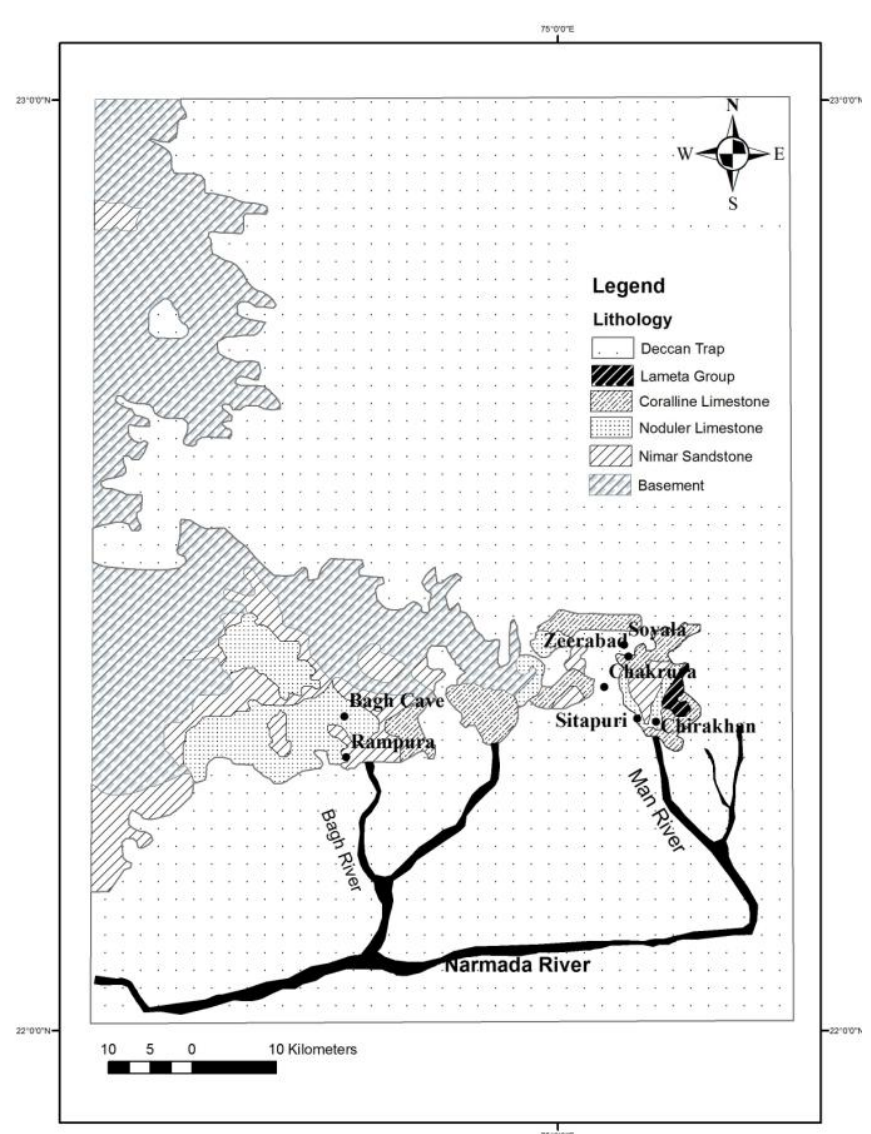

Figure 1: Geological Map (Modified after Jaitly and Ajane, 2013)

Table 1: General stratigraphy of Bagh Group after (Tripathi, 2006 and Jaitly \& Ajane, 2013)

\begin{tabular}{|c|c|c|c|}
\hline \multicolumn{4}{|c|}{ Lameta Group and Deccan Traps } \\
\hline Group & Formation & Member & Age \\
\hline \multirow{5}{*}{ Bagh } & Coralline Limestone & & Coniacian \\
\hline & \multirow{2}{*}{ Nodular Limestone } & Chirakhan & \multirow{2}{*}{ Turonian } \\
\hline & & Karondia & \\
\hline & \multirow{2}{*}{ Nimar Sandstone } & Baria & \multirow{2}{*}{ Cenomanian } \\
\hline & & Bagh cave & \\
\hline \multicolumn{4}{|c|}{ rocks } \\
\hline
\end{tabular}

\section{Systematic Palaeontology}

Authors have followed the standard methodology earlier used in Moore et al. (1969) and recently revised by Carter et al. (2011) for taxonomic description. All the measurements are in millimeter. The following abbreviations have been used for taxonomic representations:

H: height; L: length; I: Inflation; BV: both valves; LV: left valve; RV: right valve; S. No: Serial Number.

\section{Repository:}

The specimens of the present study are stored in the Stratigraphy and Invertebrate Palaeontology Laboratory, Department of Geology, Banaras Hindu University.

Subclass: Pteriomorphia Beurlen, 1944

Order: Arcida J.Gray, 1854

Superfamily: Arcoidea Lamarck, 1809

Family: Arcidae Lamarck, 1809
Subfamily: Arcinae Lamarck, 1809

Genus: Barbatia Gray, 1842

Subgenus: Cucullaearca Conard, 1865

Type species: Byssoarca lima Conard, 1847; SD Stoliczka, 1871

\section{Barbatia (Cucullaearca) cf. clellandi (Forbes)}

(Fig. 2A )

1846 Arca clellandi Forbes, p.139, p. 14, fig.4.

1871 ?Scapharca clellandi Forbes: Stoliczka, p.356, pl. 17, fig. 35.

Material: Single specimen (BHU2014/Ck1/90)

Horizon: Nodular Limestone,

Locality: Chakrur Village, Dhar distrct

Dimensions:

\begin{tabular}{|l|l|l|l|l|}
\hline S.No & Specimen No. & H (mm) & L (mm) & I (mm) \\
\hline $\mathbf{1}$ & BHU2014/ Ck1/90 & 8 & 15 & $6(\mathrm{RV})$ \\
\hline
\end{tabular}

\section{Description}

The shell is subquadrate in outline, small and moderately inflated. Umbo though broken along antero-dorsal margin, appears to be small, prosogyrous and slightly protruding above dorsal margin and situated about 25\% length from the anterior margin. A faint umbonal ridge runs obliquely towards the posterior margin. Antero-dorsal and anterior margins are broken but apparently the anterior one is broader and rounded. Postero-dorsal margin is long and straight and posterior margin feebly rounded. Both anterior and posterior margins merging smoothly with symmetrically rounded ventral margin. The ventral margin has a median sinus. Surface is ornamented with fine growth lamellae intersected by fine radial threads.

\section{Remarks}

Arca clellandi has been recorded by to Forbes (1846) from the Cretaceous rocks of Cauvery Basin which has been later doubtfully kept under the genus ?Scapharca Gray, 1847 by Stoliczka (1871, p.356). Additionally, according to Newell (in Moore et al. 1969, p. 256) the genus Scapharca ranges in age from Oligocene to Recent. The sub-quadrate outline, median sinus in ventral margin, remnant of amphidatic cardinal area and cancellate ornamentation allow us to keep Arca clellandi Forbes under Barbatia (Cucullaearca) Conard. This specimen from the Bagh Group has been assigned to Barbatia (Cucullaearca) cf. clellandi (Forbes) with qualification due to its poor state of preservation.

Subfamily: Noetiinae Stewart, 1930

Genus: Breviarca Conard, 1872

Type species: Arca centenaria Say, 1824

\section{Breviarca baghensis sp. nov.}

(Figs. 2B, C)

Material: Single specimen (BHU2014/Rn3/12)

Horizon: Nodular Limestone Formation

Locality: Near Ramapura Village, Dhar District 
International Journal of Science and Research (IJSR)

ISSN (Online): 2319-7064

Index Copernicus Value (2013): 6.14 | Impact Factor (2014): 5.611

Dimensions:

\begin{tabular}{|l|l|l|l|l|}
\hline S. No & Specimen No. & H (mm) & L (mm) & I (mm) \\
\hline $\mathbf{1}$ & BHU2014/ Rn3/12 & 8 & 11 & $4(\mathrm{RV})$ \\
\hline
\end{tabular}

Etymology: After the Bagh town, Central India.

\section{Diagnosis:}

Shell small, subtrapezoidal, postero-ventrally elongated and radially ornamented, hinge with taxodont dentition having posterior series longer than anterior one.

\section{Description:}

The present specimen represents the right valve which is small, sub-trapezoidal in outline, strongly inflated and postero-ventrally elongated. Umbo prominent, slightly raised above dorsal margin with $105^{\circ}$ umbonal angle, opisthogyrous, situated at about $40 \%$ of length from the anterior end. Antero-dorsal margin small, rounded and forming steep declivation with umbonal ridge. Anterior margin gently convex and merges smoothly with asymmetrically rounded ventral margin. Postero-dorsal margin comparatively longer with steep declivation. Posterior margin is produced and evenly rounded. Anterior umbonal ridge obtusely rounded and almost vertical. Posterior umbonal ridge is oblique and fades before reaching postero-ventral corner. Hinge long, narrow and straight with numerous transverse teeth. The posterior series of teeth longer than the anterior series. The shell surface is ornamented with numerous obtusely rounded radial ribs becoming scabrous due to presence of ventrally arcuate scales. The radials posterior to posterior ridge are finer and separated by narrower interspaces. All these radials are beaded throughout at regular intervals. The radials are forming scalloped ventral margin.

\section{Remarks:}

This specimen from the Bagh Group in its small size ( $\mathrm{L}=11$, $\mathrm{H}=8$ ) and subtrapezoidal outline is quite distinct from the all the known species of Breviarca Conard from the Late Cretaceous. The umbo is also anteriorly positioned while in most of the known species of Breviarca it is mesial to submesial. In size and surface ornamentation, the present specimen is comparable to Breviarca umbonata Conard recorded by Richards (1991, p. 83, pl. 13, figs. 12, 13) from the Cretaceous of New Jersey but in B. umbonata the umbo is mesial and the shell is subtrigonal. Breviarca habita Stephenson (1952, p. 60, pl. 10, fig. 19, 20) and also recorded by Scott (1970, p. 59, pl. 1, figs. 11-12) from Kiowa Formation, Kansas has some resemblance in size (smaller) and ornamentation but due to mesial umbo, the outline is quite different. This lone specimen is perfectly preserved and depicting all the diagnostic morphological features definitely belonged to a new species.

Family: Glacymerididae Newton, 1922

Subfamily: Glacymeridinae Newton, 1922

Genus: Glycymeris De Costa, 1778

Type species: Arca orbicularis De Costa, 1778 (= Arca glycymeris, Linné, 1758)

Glycymeris sp.

(Figs. 2D, E, F, G)
Material: Two specimens (BHU2014/Ks6/9, BHU2014/Si 7/24)

Horizon: Nodular Limestone

Locality: Kosdana and Sitapuri villages, Dhar district

Dimensions:

\begin{tabular}{|c|c|c|c|c|}
\hline S.No & Specimen No. & H (mm) & L (mm) & I (mm) \\
\hline $\mathbf{1}$ & BHU2014/ Ks6/9 & 22 & 17 & $9(\mathrm{RV})$ \\
\hline $\mathbf{2}$ & BHU2014/Si7/24 & 22 & 16 & $9(\mathrm{RV})$ \\
\hline
\end{tabular}

\section{Description and Remarks:}

The specimens are of moderate size, approaching subquadrate shape, moderately inflated and postero-ventrally elongated. Umbones small, pointed, bending inward to just reach dorsal margin of the hinge plate and not projecting beyond that. The anterior margin rather small and convex whereas posterior margin broadly concave. Shell attains its maximum inflation in the middle from where it slopes gently towards the dorsal margin and steeply towards rest of the margins. The broadly convex ventral margin meets the anterior margin at obtuse angle and with broadly concave posterior margin at acute angle. The narrow, slightly curved hinge plate consists of series of small, parallel teeth. The surface is eroded but appears to have faint concentric ribs near the postero-ventral margin. Due to broken margins, its specific identification has been differed and recorded here as Glycymeris sp.

Subfamily: Arcullaeinae Newell, 1969

Genus: Trigonarca Conard, 1862

Type species: Cucullaea macoensis Conard, 1860

\section{Trigonarca camerunensis Riedel}

(Figs. 2H, I )

1932 Trigonarca camerunensis Riedel, p.43, pl. 7, figs. 2-7

1954 Trigonarca camerunensis cameruensis Riedel, Reyment, p. 675

1957 Trigonarca camerunensis Riedel, Dertevelle \& Freneix, p. 28, pl. 2, figs. 2-9

Material: Single specimen (BHU2014/Si3/11)

Horizon: Nodular Limestone

Locality: Sitapuri Village, Dhar district

\section{Dimensions:}

\begin{tabular}{|c|c|c|c|c|}
\hline S.No & Specimen No. & H(mm) & L(mm) & I (mm) \\
\hline $\mathbf{1}$ & BHU2014/Si3/11 & 18 & 22 & $7(\mathrm{RV})$ \\
\hline
\end{tabular}

\section{Description:}

Shell small, subtrigonal, postero-ventrally elongated with moderate inflation. Length is appreciably greater than height. Umbo prominent, prosogyrous, slightly protruding above the dorsal margin and anteriorly situated. Anterodorsal margin concave and anterior margin feebly rounded and produced, postero-dorsal margin almost straight and posterior margin obliquely truncated. Both anterior and posterior margins are merging smoothly with broadly rounded ventral margin. A faint posterior carina separates a small, feebly convex posterior region. Surface is eroded but near the ventral margin coarse commarginal ribs are present. Hinge plate subarcuate having thick platforms near the 


\section{International Journal of Science and Research (IJSR) ISSN (Online): 2319-7064 \\ Index Copernicus Value (2013): 6.14 | Impact Factor (2014): 5.611}

antero-dorsal and postero-dorsal margins. The dentition consists of small series of teeth.

\section{Remarks:}

Although the lone present specimen is not much posteroventrally elongated but in its subarcuate hinge with oblique teeth and thick margins of hinge plate resembles well to Trigonarca camerunensis Riedel particularly recorded by Dertevelle \& Freneix (1957, p. 28, pl. 2, figs. 2-9) from the Cretaceous of Angola. T. camerunensis has been so far confined to Upper Cretacous (Cenomanian- Campanian) of central and east African regions, its record from the Turonian of central India is noteworthy.

\section{Trigonarca galdrina d'Orbigny}

(Fig. 2J)

1871 Trigonarca galdrina d'orbigny: Stoliczka, p. 355, pl. 18, figs. 2-5.

Material: Single specimen (BHU2014/Rn1/26)

Horizon: Nodular Limestone

Locality: Near Rampura Village, Dhar district

Dimensions:

\begin{tabular}{|c|c|c|c|c|}
\hline S. No & Specimen No. & H(mm) & L(mm) & I(mm) \\
\hline $\mathbf{1}$ & BHU2014/Rn1/26 & 8 & 13 & $6(\mathrm{LV})$ \\
\hline
\end{tabular}

\section{Description:}

Shell is small, subtrapeziodal, postero-ventrally elongated and height nearly half of the length. Umbo slightly elevated, blunt, opisthogyrous and flat. Antero-dorsal margin small and concave; anterior margin rounded, comparatively broad and merging with semi-lunar ventral margin at acute angle. Postero-dorsal margin almost straight and parallel to ventral margin; posterior margin obliquely truncated. Two umbonal carinae extend successively postero-ventrally and anteroventrally forming posterior and anterior wing like features at both the ends. The surface is crowded with fine, rounded radial ribs which are separated by broader interspaces. Few faint concentric growth lines are irregularly intersecting the radials.

\section{Remarks:}

The shell is markedly elongated in the postero-ventral direction, though quite small in size is closely comparable to T. galdrina d $\mathrm{d}^{\mathrm{ee}}$ Orbigny recorded by Stoliczka (1871, p. 355) from the Late Cretaceous of the Ariyalur, South India. Trigonoarca galdrina d'Orbigny is a highly variable species due to variations in its outline from sub-quadrate to subtrapizoidal and surface ornamentation (Kendrik and Vartak, 2007). Our specimen, though small in size, falls well within the range of characters of $T$. galdrina. Earlier $T$. galdrina has been recorded from Campanian - Maastrichtian of south India. Present record extends down its range to Turonian.

Family: Parallelodontidae Dall, 1898

Subfamily: Grammatodontinae Stephenson, 1941

Genus: Grammatodon Meek \& Hayden, 1861

Type species: Arca (Cucullaea) inornata Meek \& Hayden, 1859

Grammatodon cf. japeticum Forbes
(Figs. 2K, L )

1871 Macrodon (?Grammatodon) japeticum Forbes: Stoliczka, pl. 18, pl. 6-11

Material: Two specimens (BHU2014/K-10, Kar2/36)

Horizon: Nodular Limestone

Locality: Near Karondia Village, Dhar district

\section{Dimensions:}

\begin{tabular}{|c|c|c|c|c|}
\hline S. No & Specimen No. & $\mathrm{H}(\mathrm{mm})$ & $\mathrm{L}(\mathrm{mm})$ & $\mathrm{I}(\mathrm{mm})$ \\
\hline $\mathbf{1}$ & BHU2014/ K-10 & 12 & 18 & $12(\mathrm{BV})$ \\
\hline $\mathbf{2}$ & BHU2014/Kar2/36 & 11 & 16 & $10(\mathrm{BV})$ \\
\hline
\end{tabular}

\section{Description:}

The shell subtrapezoidal, strongly inflated with wide cardinal area. Right valve is slightly smaller and more inflated than the left valve. Umbo blunt, prosogyrous, slightly incurved anteriorly, nearly protruding from the hinge and situated at approximately at one-third of length from the anterior end. Both antero-dorsal and postero-dorsal margins are feebly concave. Anterior margin rounded whereas posterior margin slightly produced and both are merging with straight ventral margin in regular curves. A faint carina extends obliquely from umbo to postero-ventral corner. Ornamentation is obscured by erosion.

\section{Remarks:}

The present specimen closely resembles to Grammatodon japeticum Stoliczka (1871, p. 350, pl. 18, figs. 6-11) from south India in most of the characters, but in view of the absence of surface ornamentation, it has been tentatively assigned to $G$. cf. japeticum. It has almost similar outline as in Grammatodon (Nanonavis) subcrenulatus Kendrik and Vartack (2007, p. 20, figs. 3E-J) recorded from Karai Formation (Albian), Cauvery Basin, south India but is less inflated and possesses faint umbonal carina. G. (N.) yokoyamai Yabe and Nagao from the Upper Neocomian Albian of Japan by Hayami ( 1980, p. 428-430, pI.52, figs 16) closely resembles to the present species but Japanese species has prominent cancellate ornamentation along with sharp anterior and posterior umbonal carinae.

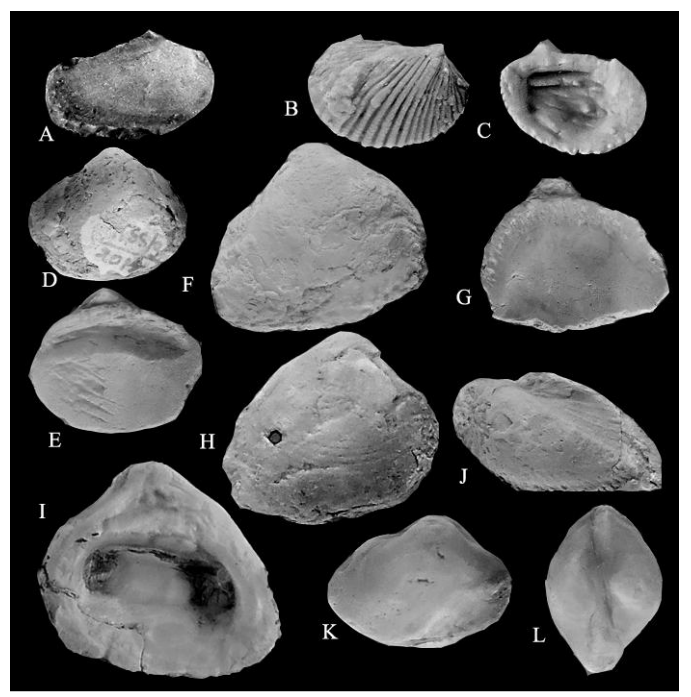

Figure 2: Arcid Bivalve from Nodular Limestone Formation (Turonian), Bagh Group. 


\section{International Journal of Science and Research (IJSR) \\ ISSN (Online): 2319-7064 \\ Index Copernicus Value (2013): 6.14 | Impact Factor (2014): 5.611}

A Barbatia (Cucullaearca) cf. clellandi (Stoliczka, 1871) External view of right valve x2 (specimen no. BHU2014 ck1/90).

B, C Breviarca baghensis sp. nov. B.External view of right valve x2 (specimen no. BHU2014 Rn3/12), C. Internal view of right valve $\mathrm{x} 2$ (same specimen).

D, E, F, G Glycymeris sp. D. External view of right valve x1.5 (specimen no. BHU2014 Ks6/9), E. Internal view of right valve x1.5 (same specimen), F. External view of right valve x1.5 (specimen no. BHU2014 Si7/24), G. Internal view of right valve $\mathrm{x} 1.5$ (same specimen).

H, I Trigonarca camerunensis Riedel (Dertevelle and Freneix,1957) H. External view of right valve x1.5 (specimen no. BHU2014 Si3/11), I. Internal view of right valve x1.5 (same specimen).

J. Trigonarca galdrina d'Orbigny (Stoliczka, 1871) External view of left valve x2 (specimen no. BHU2014 $\mathrm{Rn} 1 / 26)$.

K, L Grammatodon cf. japeticum Forbes (Stoliczka, 1871) K. External view of Right valve x1.5 (specimen no. BHU2014 K-10) L. Dorsal view x1.5 (same specimen).

\section{Acknowledgements}

The authors extend their thanks to the Head, Centre of Advanced Study, Department Geology, Banaras Hindu University, for providing necessary facilities to carry out the present work.

\section{References}

[1] S.K. Acharyya, J.R. Kayal, A. Roy, R.K. Chaturvedi, "Jabalpur earth quake of May 22, 1997: constraint from a afters shock study," Journal of the Geological Society of India, 51: pp. 295-304, 1998.

[2] K. Akhatar, D.A. Khan, "A tidal island model for carbonate sedimentation: Karondia Limestone of Cretaceous Narmada Basin, India," Journal of the Geological Society of India, 50: pp. 481-490, 1997.

[3] S.P. Anand, M. Rajaram, Crustal structure of NarmadaSon Lineament: An aeromagnetic perspective, E-latter, Earth planate space: e9-e12, 2004.

[4] S.K. Biswas, S.V. Deshpande, " Geology and Hydrocarbon prospects of Kutch, Saurashtra and Narmada Basins. In Petroliferous basins of india (eds L.L. Bhandari, B.S.Venkatachala, R.Kumar, S.N. Swamy, P. Gerga and D.C. Srivastava), ${ }^{\text {ceee }}$ Petroleum Asia Journal, KDMIPE, Oil and Natural Gas Commission, Dehradun, pp. 111-126, 1983.

[5] S.K. Biswas, " A review on the evolution of rift basins of India During Gondwana with special reference to Western Indian basins and their Hydrocarbon prospects," PINSA 65 A, No.3, pp. 261-283, 1999.

[6] S. K. Biswas, "A Review of structure and tectonics of Kutch basin, Western India with special reference to earthquakes," Current Science, 88(10): pp. 1592-1600, 2005.
[7] P.N. Bose, "Geology of the Lower Narmada valley between Namawar and Kawant," Memoir Geological Survey of India, 21(1): pp. 72, 1884.

[8] D. Buick, Ph.D. Thesis,. The rise and fall of the Cucullaeidae: Exploring transitions in species richness, geographic range, morphology and ecology in a relict bivalve family., University of Cincinnati, 2010.

[9] J.G. Carter, C.R. Altaba, L.C. Anderson, R. Araujo, A.S. Biakov, A.E. Bogan, D.C. Campbell, M. Campbell, C. Jin-hua, C.W. John, J.C.W Cope, G. Delvene, H.H. Dijkstra, , F. Zong-jie, R.N. Gardner, V.A. Gavrilova, I.A. Goncharova, J. Peter, P.J. Harries, J.H. Hartman, , M. Hautmann, W.R. Hoeh, J. Hylleberg, J. Bao-yu, P. Johnston, L. Kirkendale, K. Kleemann, J. Koppka, Jirí Kríž, D. Machado, N. Malchus, , A. Márquez-Aliaga, J. Masse, C.A. McRoberts, P.U., Middelfart, S. Mitchell, L.A. Nevesskaja, S. Özer, J. Pojeta, I.V.Jr. Polubotko, J.M. Pons, S. Popov, T. Sánchez, A.F. Sartori, R.W. Scott, I.I. Sey, J.H. Signorelli, V.V. Silantiev, P.W. Skelton, T. Steuber, J.B. Waterhouse, G.L. Wingard and T.Yancey, "A Synoptical classification of Bivalvia (Mollusca)," Palaeontological Contributions, pp. 1-47, 2011

[10]U. Chandra, "Earth quakes of peninsular India: Aseismotectonic study," Bulletin of the Seismological Society of America, 65: pp. 1387-1413, 1977.

[11]E. Dartevelle, S. Freneix, "Mollusques fossils du Crétacé de la côte occidentale d"Afrique du Cameroun à l'Angola II- Lamellibranches," Sciences géologiques, 20: pp. 1-271, 1957.

[12]E. Forbes, "Report on the fossils Invertebrate from the Southern India, collected by M.M. Kaye and Cunliffe," Transaction of the Geological Society of London, 7.(2): pp. 97-174, 1846.

[13] J.E. Gray, "A list of the genera of Recent Mollusca, their synonyms and types," Zoological Society of London Proceeding, 15: pp. 129-229, 1857.

[14] H.K. Gupta, R.K. Chaddha, M.N. Rao, B.L. Narayna, P. Mandal, M. Ravikumar, N. Kumar, "The Japalbur earth quake of May 22,1997," Journal of the Geological Society of India, 50: pp. 85-91, 1997.

[15] I. Hayami, T. Oji, "Early Cretaceous bivalvia from the Choshi district, Chiba prefecture, Japan ," Transaction Proceeding Palaeontological Society of Japan, 120: pp. 419-448, 1980

[16] A.K. Jaitly, F.T. Fürsich, M. Heinze, "Contributions to the Jurassic of Kuchchh, Western India. IV. The bivalve fauna Part-1 Sub-class Palaeotaxodonta, Pteriomorphia, and Isofilibranchia," Beringena, 16: 147-257, 1995.

[17]A. K. Jaitly, R. Ajane, " Comments on Placenticeras mintoi (Vredenburg, 1906) from the BaghBeds (Late Cretaceous), Central India with Special Reference to Turonian Nodular Limestone Horizon," Journal of the Geological Society of India, 81: pp. 565-574, 2013.

[18]G.W. Kendrick, A.V. Vartak, "Middle Cretaceous Cenomanian bivalves from the Karai Formation, Uttattur Group, of the Cauvery Basin, South India," Records of Western Australian Museum Supplement, 72: pp. 1-101, 2007.

[19]A.A. Khan, M. Aziz, "Quaternary Tectonics \& Sedimentation in Narmada Rift Valley, With Special Reference to Garudeshwar and Bharuch Section Gujarat 


\section{International Journal of Science and Research (IJSR) \\ ISSN (Online): 2319-7064}

Index Copernicus Value (2013): 6.14 | Impact Factor (2014): 5.611

State India," International Journal of Advance research, 3: pp. 430-457, 2015.

[20] S. Kumar, M.P. Singh, D.M. Mohabey, "Lameta and Bagh Beds, Central India (field Guide)," Palaeontological Society of India, pp. 1-44, 1999.

[21] S.S. Merh, Geology of Gujarat, Geological society of India, Banglore, 1995.

[22] C.R. Moore, L.R. Cox, N.D. Newell, D.W. Boyd, C.C. Branson, C. Raymond, A. Chavan, A.H. Coogan, C. Dechaseaux, C.A. Fleming, F.Haas, L.G. Hertlein, E.G. Kauffman, A.M. Keen, A. LaRocque, A.L. McAlester, C.P. Nuttal, B.F. Parkins, H.S. Puri, L.A. Smith, T. Soot-Reyn, H.B. Stenzel, E.R. Thurman, R.D. Turner, J. Weir , Treatise on Invertebrate Palaeontology, Geological Society of America pp. 1:1969.

[23]R. A. Reyment, "The stratigraphy of the Southern Cameroons," Geol. Fôren. Forhandl. Stockholm, Bd. 76, $\mathrm{N}^{\circ}$ 479: pp. 661-683, 1954.

[24] H.G. Richards, C.W. Cooke, H.F. Garner, B.F. Howell, J.A. Jeletzky, A.K. Miller, H.W. Jr. Miller, R.C.Ramsdell, J.B. Jr. Reeside, H.B. Roberts, J.W. Wells, "The Cretaceous fossils of New Jersey," Paleontology series part-1: pp. 1-263, 1991.

[25] L. Riedel, "Die Oberkreide vom Mungofluss in Kamerun und ihre Fauna," Beitr. Geol. Erfosch. deut. Schutzgeb, H 16: 154, 1932.

[26] K.P. Rode, G.W. Chiplonkar, "A contribution to the Stratigraphy of Bagh Beds,” Current Science 4(5): pp. 322-323, 1935

[27] R.W. Scott, "Paleoecology and Paleontology of the Lower Cretaceous Kiowa Formation, Kansas ," Article 52 (Cretaceous 1) University of Kansas Paleontological contribution, 59: pp. 1-102, 1970.

[28] S. K. Singh, H. K.Srivastava, "Lthostratigraphy of the Bagh Beds and Its Correlateion with Lameta Beds," Journal of Palaeontological Society of India, 26: pp. 7785, 1981.

[29] S. Souji, T. Radhakrishnan, "New distribution record and Taxonomy of Two Cucullaeidae Species (Bivalvia: Arcacea) from Thermal Beach, Thoothukudi, SouthEast coast of India," International Journal of Science and Research, 2319-7064: pp. 939-943, 2013.

[30] L.W. Stephenson, "Larger Invertebrate fossils of the Woodbine Formation (Cenomanian) of Texas" U.S. Geological Survey, Professional Paper, 242: pp. 1-226, 1952.

[31]F. Stoliczka, "Cretaceous fauna of southern India. The Pelecypoda, with a review of all known genera of this class, fossil and recent," Memoir Geological Survey of India, Palaentologica Indica, Series 6, 3: pp.1-1537, 1871.

[32] R.D.K.Thomas, A. Madzvamuse, P.K. Maini, A.J. Wathen "Growth patterns of noetiid ligaments: implications of developmental models for the origin of an evolutionary novelty among arcoid bivalves(abstract)," Geological society of London, 2000.s

[33] S.C. Tripathi, "Geology and Evolution of the Cretaceous infratrappean Basins of Lower Narmada valley, Western India” 67: pp. 459-567, 2006.

[34] W.D. West, "The line of the Narmada and Son valleys," Current Science 4: pp. 143-144, 1962.

\section{Author Profile}

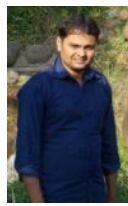

S. Kumar has completed his Post Graduation in Petroleum Geosciences and presently pursuing Ph.D. in Geology. He is working on the problem " Palaeoecology and Taphonomy of Late Cretaceous Bivalves, Bagh Beds, M.P., Central India”. He is interested in Cretaceous invertebrates, their functional morphology and diverse implications.

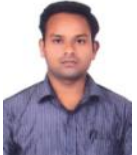

Jai P. Gautam is M. Sc. (Petroleum Geosciences) and carrying out his researches on Cretaceous invertebrate fauna of the Cauvery basin, SE India emphasizing biostratigraphy, palaeocolgy and palaeobiogeography.

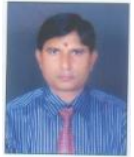

Dr. B. Pandey is M. Sc. and Ph. D. in Geology presently teaching faculty in the Department of Geology, BHU, Varanasi . He is working on Indian marine Jurassic - Cretaceous sedimentary successions in context of biostratigraphy, palaeobiogeography and taxonomic study of mega invertebrates in general and ammonoids in particular since last several years.

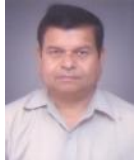

Dr. D. B. Pathak is M. Sc. and Ph. D. in Geology, having research experience for over 25 years and contributed a lot in the field of mega invertebrate palaeontology, biostratigraphy, palaeobiogeography and other applied aspects of palaeontology particularly in different Mesozoic basins of India.

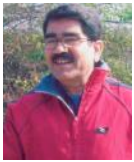

Prof. Anand K. Jaitly is M.Sc., PhD in Geology and has more than forty years of experience of working on the Mesozoic bivalves. Presently engaged in the palaeoecological and taphonomic studies of the Mesozoic macrofauna of Kachchh, Narmada and Cauvery basins to evaluate the history of evolution of these basins. 